Review Article

\title{
Darbepoetin alfa: review in the management of anemia in patients with chronic kidney disease
}

\author{
Hanmant Barkate ${ }^{1}$, Jatin Kothari ${ }^{2}$, Himanshu Patel ${ }^{3}$, A. V. Ingale ${ }^{4}$, Salman Motlekar ${ }^{1}$
}

\begin{abstract}
${ }^{1}$ Department of Medical Affairs, Wockhardt Limited, Mumbai, Maharashtra, India

${ }^{2}$ Department of Nephrology and Transplant, Hinduja Hospital, Mumbai, Maharashtra, India ${ }^{3}$ Department of Nephrology and Renal Transplantation, Zydus Hospital, Ahmedabad, Gujarat, India

${ }^{4}$ Department of Nephrology and Renal Transplantation, Fortis Group of Hospitals, Mumbai, Maharashtra, India
\end{abstract}

Received: 27 December 2016 Accepted: 01 February 2017

\section{*Correspondence to: \\ Dr. Hanmant Barkate, \\ Email: \\ HBarkate@wockhardt.com}

Copyright: (C) the author(s), publisher and licensee Medip Academy. This is an openaccess article distributed under the terms of the Creative Commons Attribution NonCommercial License, which permits unrestricted noncommercial use, distribution, and reproduction in any medium, provided the original work is properly cited.

\begin{abstract}
Chronic kidney disease (CKD) is a significant clinical problem across the world including India. The SEEK (Screening and Early Evaluation of Kidney Disease) study from India reported the prevalence of CKD as $17.2 \%$. Diabetic nephropathy, undetermined etiology, chronic glomerulonephritis and hypertensive nephrosclerosis are the common causes of CKD in India. Rising rates of diabetes and hypertension, late presentation of patients to nephrologists and limited number of nephrologists in India adds to the concerns related to management of CKD. Considering the pathophysiology of CKD, anemia is almost an inevitable complication in these patients. Untreated anemia significantly contributes to the morbidity and mortality associated with CKD. Early recognition, timely management with appropriate therapy helps to reduce the complications of anemia. Erythropoiesis-stimulating agents (ESAs) are one of the important measures for correction of anemia in CKD patients. Darbepoetin, an ESA is a valuable therapeutic option for the treatment of anemia in CKD patients and has played a vital role in enhancing anemia management. In this article we reviewed the efficacy and safety data along with key benefits and place of darbepoetin alfa in the management of anemia in CKD patients.
\end{abstract}

Keywords: Anemia, Chronic kidney disease, Darbepoetin, India

\section{INTRODUCTION}

Chronic kidney disease (CKD) is a global clinical concern across the world. With increased life expectancy and rising rates of lifestyle disorders, prevalence of CKD majorly contributed by non-communicable diseases such as diabetes and hypertension is on rise. These two common conditions are the major contributors for CKD in India too. ${ }^{1}$ The prevalence of CKD is high both in rural and urban parts of India. The rates of CKD in different studies differ because of the different methods used for estimating the prevalence. For instance, a study from rural population in Karnataka reported CKD in $6.3 \%$ by using glomerular filtration rate (GFR) estimation by modification of diet in renal disease (MDRD) and $16.54 \%$ by Cockcroft-Gault equation corrected to the body surface area. ${ }^{2}$ The SEEK (Screening and Early Evaluation of Kidney Disease) study from India with a 
cohort of 5588 subjects reported the prevalence of $17.2 \%$ with approximately $6 \%$ patients presenting in stage 3 or above (stage 3-4.3\%; stage $4-0.8 \%$ and stage $5-0.8 \%$ ) with large variations among different centers. Hypertension, anemia, diabetes, obesity, history of ischemic heart disease and history of hypercholesterolemia was significantly more common in patients with CKD compared to those with non CKD. ${ }^{3}$ According to the first report of Indian registry published in 2012 diabetic nephropathy (31\%) is the commonest cause of CKD. ${ }^{4}$ The reported rates of CKD in India due to undetermined etiology, chronic glomerulonephritis and hypertensive nephrosclerosis in this registry were $16 \%$, $14 \%$ and $13 \%$ respectively.One of the major challenges for management of CKD in India is late presentation of patients to the nephrologist. Indian CKD registry reported close to $48 \%$ patients presenting in stage $\mathrm{V}$.

Among different problems associated with CKD, anemia is a common clinical concern and is an early complication in this patients. ${ }^{5-7}$ The prevalence of anemia defined as hemoglobin less than $12 \mathrm{~g} / \mathrm{dL}$ is progressively higher from stage 1 to stage 5 CKD. In a study, anemia was reported among $42 \%$ patients of stage 1 whereas it was seen in $82 \%$ patients of stage 5 . The corresponding percentage of patients with hemoglobin less than $11 \mathrm{~g} / \mathrm{dL}$ was $21 \%$ (stage $1 \mathrm{CKD}$ ) and $72 \%$ (stage $5 \mathrm{CKD}$ ). ${ }^{6}$ In Indian studies anemia has been shown to be present in 94\%-100\% patients with CKD. ${ }^{8-10}$

The pathophysiology of anemia is complex. Cardiorenalanemia syndrome is a vicious cycle wherein congestive heart failure can lead to CKD as well as it can be the result of CKD (Figure 1). Congestive heart failure can either directly cause renal injury or through inflammation initiated by cytokines which adversely affect the erythropoiesis and iron metabolism. Diminished cardiac output impairs the blood supply to kidneys resulting in renal ischemia, the consequence of which is progression of anemia due to impaired hormonal function of the kidney. ${ }^{11}$

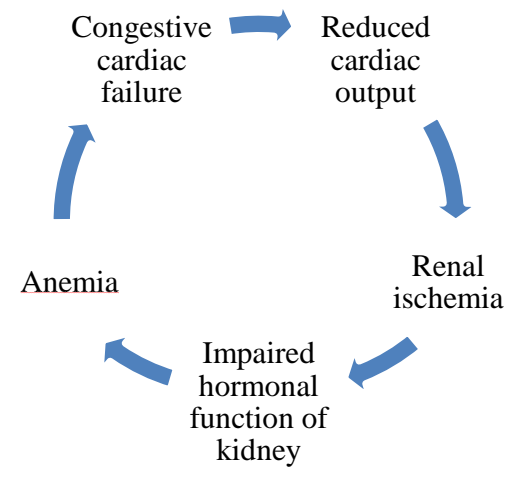

Figure 1: Vicious cycle of congestive heart failure and

Untreated anemia in patients with chronic renal failure can lead to several consequences including increased need for hospitalizations, serious cardiovascular problems such as left ventricular dysfunction and left ventricular hypertrophy, increased requirement for blood transfusions, impaired quality of life and increased risk of death. ${ }^{7} 12$ Left ventricular hypertrophy is a known risk factor for cardiac morbidity and mortality. ${ }^{7}$

In diagnosed cases of anemia with hemoglobin levels less than $11 \mathrm{~g} / \mathrm{dl}$, other causes should be ruled out. Iron deficiency, as a cause of anemia, if present should be corrected. Early and effective treatment of anemia is important for achieving positive outcome in terms of morbidity and mortality. ${ }^{7}$ The optimal hemoglobin level is a subject of debate. ${ }^{5}$ Generally it is agreed that evaluation of anemia in CKD is started when hemoglobin level is reduced to $12 \mathrm{~g} / \mathrm{dL}$ and the therapy should be started when hemoglobin level goes below $11 \mathrm{~g} / \mathrm{dL} .{ }^{5}$ Data suggest that hemoglobin level should be maintained above $11 \mathrm{~g} / \mathrm{dL}$ in order to protect the cardiac functions. ${ }^{12}$ Hemoglobin level of around $12 \mathrm{~g} / \mathrm{dL}$ seems to be better in improving left ventricular mass index and the quality of life in pre-dialysis patients compared to conventional hemoglobin levels. ${ }^{5}$

Introduction of erythropoiesis-stimulating agents (ESAs) is a major advance in the management of anemia associated with CKD. Correction of anemia by ESAs can reduce left ventricular hypertrophy and stress on the heart, resulting in reduced risks for cardiovascular disease in CKD patients. ${ }^{13}$ Effective therapy of anemia helps in improving overall survival of the patients and also the quality of life. ${ }^{14}$ In this regards, ESA represents one of the most important means and mainstay of correcting anemia in CKD patients. ${ }^{15}$ These agents cause increase in the level of hemoglobin in patients with anemia in CKD and reduce requirement for blood transfusion. In CKD patients, administration of these agents helps to improve the survival. ${ }^{16}$

In this article, we reviewed data on darbepoetin by systematically searching publications identified by PubMed, Google scholar from 1999 to 2016 with search items: anemia, darbepoetin alfa, chronic kidney disease, epoetin alfa, erythropoiesis stimulating agent, renal replacement therapy. Literature was not limited by study design and all types of studies including randomized, double blind, cohort, case-control, observational and retrospective studies were included. Animal studies were not considered for the efficacy and safety review. Though we have taken utmost care to include all relevant literature, non-inclusion of any literature is unconditional, unbiased and unintentional.

\section{DARBEPOETIN ALFA}

The commonly used ESAs are epoetin alfa and darbepoetin alfa, both of them have the same protein sequence but there is difference in their glycosylation. Darbepoetin stimulates the process of erythropoiesis by similar mechanism as that of endogenous erythropoietin. 
Darbepoetin offers advantages of greater potency and longer half-life and potential for extended dosing. ${ }^{17,18}$

\section{PHARMACOKINETICS}

Pharmacokinetics of darbepoetin alfa has been studied with intravenous (IV) and subcutaneous (SC) administration. The pharmacokinetic parameters in CKD patients are shown in the Table $1 .^{17,19}$

\section{Table 1: Pharmacokinetic parameters of intravenous darbepoetin alfa.}

\begin{tabular}{|ll|}
\hline Pharmacokinetic parameter & Darbepoetin alfa \\
\hline $\begin{array}{l}\text { Absorption (SC administration) } \\
\text { Bioavailability in patients on } \\
\text { dialysis (SC administration) }\end{array}$ & Slow \\
\hline $\begin{array}{l}\text { Volume of distribution (IV } \\
\text { administration) }\end{array}$ & $\sim 37 \%$ \\
\hline Cmax (SC administration) & $\begin{array}{l}48 \text { hours }(12-72 \\
\text { hours })\end{array}$ \\
\hline $\begin{array}{l}\text { Area under the serum } \\
\text { concentration (IV administration) }\end{array}$ & $\begin{array}{l}291.0+7.6 \\
\text { ng.h/mL }\end{array}$ \\
\hline Clearance (IV administration) & $1.6+0.3 \mathrm{~mL} / \mathrm{h} / \mathrm{kg}$ \\
\hline $\begin{array}{l}\text { Terminal elimination half-life (IV } \\
\text { administration) }\end{array}$ & $25.3 \mathrm{hours}$ \\
\hline $\begin{array}{l}\text { Terminal elimination half-life in } \\
\text { patients on dialysis (SC } \\
\text { administration) }\end{array}$ & $\begin{array}{l}46 \text { hours (range } \\
12-89 \text { hours) }\end{array}$ \\
\hline $\begin{array}{l}\text { Terminal elimination half-life in } \\
\text { patients not on dialysis (SC } \\
\text { administration) }\end{array}$ & $\begin{array}{l}70 \text { hours (range } \\
35-139 \text { hours) }\end{array}$ \\
\hline
\end{tabular}

Intravenous administration of darbepoetin in CKD patients on dialysis results in biphasic serum concentration pattern, with distribution half-life of about 1.4 hours and a longer terminal elimination half-life. ${ }^{19}$ Darbepoetin has almost three times longer half-life compared to IV recombinant human erythropoietin
(rHuEPO). The half-life of darbepoetin is about 25.3 hours compared to 8.5 hours of rHuEPO. ${ }^{18}$ Apparent clearance is faster in patients on dialysis compared to those not on dialysis. In children with CKD, Cmax and half-life is similar to those in adult patients with CKD on dialysis. However, subcutaneous dose in children results in higher average bioavailability compared to adult patients on dialysis. ${ }^{19}$

\section{EFFICACY IN PRE-DIALYSIS PATIENTS}

Darbepoetin alfa can be used as effective and safe maintenance therapy for anemia in pre-dialysis patients. A 24 week clinical trial evaluated efficacy and safety of darbepoetin alfa in predialysis patients $(n=42)$ previously treated with once-weekly epoetin alfa. The patients were switched to once in two week to darbepoetin alfa administered subcutaneously, dose of which was given to adjust hemoglobin between 11 and $13 \mathrm{~g} / \mathrm{dL}$. Follow up of 39 patients showed consistently significant increase in hemoglobin levels at eight weeks $(0.39$; p <0.002), 16 weeks (0.58; p <0.001), and 24 weeks $(0.83 \mathrm{~g} / \mathrm{dL} ; \mathrm{p}$ <0.001). The rise in hemoglobin was seen despite reduction of darbepoetin dose up to $15 \%$ at 24 weeks. There were no adverse events related to the drug. ${ }^{20}$ Another clinical trial showed that darbepoetin alfa administered once monthly is an efficacious option for the treatment of anemia in patients with CKD. ${ }^{21}$

Continuous erythropoietin receptor activator (CERA) is gaining importance for the treatment of anemia in CKD patients because of its potential to maintain a stable hemoglobin level due to its longer half-life compared to darbepoetin alfa. However, the results of comparative clinical trials are not consistent. One study concluded that CERA could be more effective for correction of anemia in pre-dialysis patients. ${ }^{22}$ The results of another study conducted in predialysis patients suggested no significant difference in the effects in regards to achievement of target hemoglobin levels in both groups (Table 2). ${ }^{23}$

Table 2: Summary of studies with darbepoetin alfa for the treatment of anemia in CKD patients not on dialysis.

\begin{tabular}{|c|c|c|c|c|}
\hline Reference & $\begin{array}{l}\text { Number of } \\
\text { patients }\end{array}$ & Study design & $\begin{array}{l}\text { Administration of } \\
\text { darbepoetin }\end{array}$ & Outcome with darbepoetin alfa \\
\hline $\begin{array}{l}\text { Molina M, } \\
\text { et } \mathrm{al}^{20}\end{array}$ & 42 & $\begin{array}{l}\text { Prospective, } \\
\text { comparative study }\end{array}$ & $\begin{array}{l}\text { S.C. darbepoetin alfa once } \\
\text { every other week }\end{array}$ & Superior to epoetin alfa \\
\hline $\begin{array}{l}\text { Martinez } \\
\text { PM, et al }\end{array}$ & $\begin{array}{l}12 \text { (three } \\
\text { months) and } \\
\text { seven (one year) }\end{array}$ & Prospective study & $\begin{array}{l}\text { S.C. darbepoetin alfa once } \\
\text { a month }\end{array}$ & $\begin{array}{l}\text { Effective in maintaining } \\
\text { hemoglobin }>11 \mathrm{~g} / \mathrm{dL}\end{array}$ \\
\hline $\begin{array}{l}\text { Koibuchi K, } \\
\text { et } \mathrm{al}^{22}\end{array}$ & 128 & $\begin{array}{l}\text { Retrospective } \\
\text { study }\end{array}$ & $\begin{array}{l}\text { As per approved usage in } \\
\text { Japan }\end{array}$ & $\begin{array}{l}\text { Significant decrease in } \\
\text { hemoglobin over } 6 \text { months in } \\
\text { darbepoetin alfa group compared } \\
\text { to CERA }\end{array}$ \\
\hline $\begin{array}{l}\text { Furukawa T, } \\
\text { et } \mathrm{al}^{23}\end{array}$ & 29 & $\begin{array}{l}\text { Randomized, } \\
\text { controlled trial }\end{array}$ & $\begin{array}{l}\text { subcutaneous CERA or } \\
\text { DA once every four weeks }\end{array}$ & $\begin{array}{l}\text { Similar effects on hemoglobin } \\
\text { levels }\end{array}$ \\
\hline $\begin{array}{l}\text { Hoggard J, } \\
\text { et } \mathrm{al}^{24}\end{array}$ & 442 & Prospective study & $\begin{array}{l}\text { Darbepoetin once monthly } \\
\text { or Epoetin alfa once- } \\
\text { weekly or once-every- } \\
\text { other-weekly }\end{array}$ & $\begin{array}{l}\text { Higher preference to once a } \\
\text { month darbepoetin alfa }\end{array}$ \\
\hline
\end{tabular}


Compliance is an important factor that determines the success of treatment and in this regards, patient's preference is considered as one of the important factors. Medicines which are preferred by the patients are more likely to be taken by them for longer period. A study has shown that patients usually prefer once monthly darbepoetin alfa compared to once week epoetin alfa. ${ }^{24}$

In pre-dialysis patients, poor nutrition and presence of inflammation may need higher doses for the correction of anemia. $^{14,25}$ Moreover, female sex and cardiovascular disease have also been shown to be risk factors for requirement of high dose. ${ }^{25}$

\section{EFFICACY IN PATIENTS ON DIALYSIS}

Epoetin alfa and darbepoetin alfa both can be used for the treatment of anemia in patients on dialysis. Several studies have evaluated efficacy and safety of darbepoetin alfa in the treatment of anemia in these patients. In a Phase IIIb study of 24 weeks patients on dialysis receiving $\mathrm{rHuEPO}$ twice or twice a week were switched to darbepoetin alfa once a week whereas those receiving once a week were switched to darbepoetin alfa once every two weeks. The route of administration was not changed while switching to darbepoetin alfa. The study involved patients on both hemodialysis as well as peritoneal dialysis. Treatment-related adverse events were observed in 3\% patients. $^{26}$ Many hemodialysis centers use darbepoetin-alfa as the preferred agent for the treatment of anemia in CKD patients. In a study 98 hemodialysis outpatients, were switched from twice to thrice weekly epoetin alfa to darbepoetin alfa. Both the agents were similar in effectiveness. ${ }^{27}$
In another small clinical trial, efficacy of darbepoetin was examined with monthly dosage frequency. Patients receiving mean initial biweekly dose of $57 \pm 10.0 \mu \mathrm{g}$ were switched to monthly regimen with increase in dosage once they maintained target levels of hemoglobin. After switching to darbepoetin monthly regimen, hemoglobin levels were maintained in the therapeutic range throughout the study. Thus, monthly dosing frequency was found to be effective and safe over one year. Dosage schedule of monthly administration has significant potential to improve the compliance because of the convenience to patients. ${ }^{28} \mathrm{~A}$ retrospective study involving 150 adult patients on chronic hemodialysis receiving darbepoetin to achieve target hemoglobin levels of 11-13 $\mathrm{g} / \mathrm{dL}$ proved its efficacy. ${ }^{29}$

Darbepoetin has also been studied in patients on peritoneal dialysis who were switched from epoetin alfa. Darbepoetin-alfa was successful in maintaining stable hemoglobin levels in these patients without any significant adverse events. The percentage of patients with hemoglobin between $11-13 \mathrm{~g} / \mathrm{dL}$ was higher with the darbepoetin $(85 \%$ vs $73 \%){ }^{30}$

In a large multicenter observational study $(n=741)$ darbepoetin alfa has also been studied with once every 2 weeks administration for one year in adult patients with mean age of 61 years. The study is significant in terms of high completion rate. A total of $86 \%$ patients completed the study and $70 \%$ were on darbepoetin alfa once every 2 week dose schedule. Mean hemoglobin level 6 months before conversion, at the time of conversion and 12 months after conversion was $11.69,12.25$ and $11.88 \mathrm{~g} / \mathrm{dl}$ respectively.

Table 3: Summary of studies with darbepoetinalfa for the treatment of anemia in dialysis patients.

\begin{tabular}{|c|c|c|c|c|}
\hline Reference & $\begin{array}{l}\text { Number of } \\
\text { patients }\end{array}$ & Study design & Administration of darbepoetin & Outcome with darbepoetin \\
\hline $\begin{array}{l}\text { Bristoyiann } \\
\text { is } \mathrm{G} \text {, et } \mathrm{al}^{26}\end{array}$ & $\begin{array}{l}173 \text { patients } \\
\text { on dialysis }\end{array}$ & $\begin{array}{l}\text { Phase IIIb, multi } \\
\text { center, open- } \\
\text { label study }\end{array}$ & $\begin{array}{l}\text { Darbepoetin alfa once a week or } \\
\text { once in two weeks; intravenous } \\
\text { or subcutaneous. }\end{array}$ & $\begin{array}{l}\text { Effective maintenance of } \\
\text { hemoglobin at less frequent } \\
\text { dosing interval }\end{array}$ \\
\hline $\begin{array}{l}\text { Agrawal V, } \\
\text { et al }\end{array}$ & $\begin{array}{l}98 \text { patients on } \\
\text { hemodialysis }\end{array}$ & $\begin{array}{l}\text { Observational } \\
\text { study }\end{array}$ & Darbepoetin alfa once a week & As effective as epoetin alfa \\
\hline $\begin{array}{l}\text { Alsaran K, } \\
\text { et } \mathrm{al}^{28}\end{array}$ & $\begin{array}{l}26 \text { patients on } \\
\text { hemodialysis }\end{array}$ & Prospective study & $\begin{array}{l}\text { Darbepoetin- alpha fortnightly to } \\
\text { monthly intravenous }\end{array}$ & $\begin{array}{l}\text { Effective and safe for } 12 \\
\text { month treatment period }\end{array}$ \\
\hline $\begin{array}{l}\text { Nguyen } \mathrm{T}, \\
\text { et } \mathrm{al}^{29}\end{array}$ & $\begin{array}{l}150 \text { patients } \\
\text { on chronic } \\
\text { hemodialysis }\end{array}$ & $\begin{array}{l}\text { Retrospective } \\
\text { study }\end{array}$ & $\begin{array}{l}\text { Darbepoetin alfa intravenously } \\
\text { every week or two-weekly }\end{array}$ & Effective in controlling anemia \\
\hline $\begin{array}{l}\text { Remon C, } \\
\text { et } \mathrm{al}^{30}\end{array}$ & $\begin{array}{l}35 \text { patients on } \\
\text { peritoneal } \\
\text { dialysis }\end{array}$ & Not specified & Darbepoetin alfa, subcutaneously & $\begin{array}{l}\text { Percentage of patients with } \\
\text { hemoglobin between } 11- \\
13 \mathrm{~g} / \mathrm{dL} \text { increased from } 73 \% \text { in } \\
\text { epoetin to } 85 \% \text { in darbepoetin }\end{array}$ \\
\hline $\begin{array}{l}\text { Feriani M, } \\
\text { et al }\end{array}$ & $\begin{array}{l}741 \text { patients } \\
\text { on peritoneal } \\
\text { dialysis }\end{array}$ & $\begin{array}{l}\text { Multicenter, } \\
\text { observational } \\
\text { study }\end{array}$ & $\begin{array}{l}\text { Darbepoetin alfa once in two } \\
\text { weeks }\end{array}$ & $\begin{array}{l}\text { Effective in maintaining } \\
\text { hemoglobin level }>11.0 \mathrm{~g} / \mathrm{dL} \\
\text { in } 73 \% \text { patients }\end{array}$ \\
\hline $\begin{array}{l}\text { Locatelli F, } \\
\text { et } \mathrm{al}^{32}\end{array}$ & $\begin{array}{l}341 \text { patients } \\
\text { on dialysis }\end{array}$ & $\begin{array}{l}\text { Multicenter, open } \\
\text { label study }\end{array}$ & $\begin{array}{l}\text { Darbepoetin alfa once a week or } \\
\text { once in two weeks intravenously } \\
\text { or subcutaneously }\end{array}$ & $\begin{array}{l}\text { Effective and safe in } \\
\text { maintaining target hemoglobin } \\
\text { level }\end{array}$ \\
\hline
\end{tabular}


After one year of conversion, $73 \%$ patients were having hemoglobin level above $11.0 \mathrm{~g} / \mathrm{dL}$. There was no increase in the mean dosage. ${ }^{31}$ In another study involving 341 patients on dialysis rHuEpo treatment was changed to darbepoetin alfa with reduced frequency of administration with same route of administration i.e. intravenous or subcutaneous (Table 3). Those receiving rHuEpo two/ three times weekly were given once-weekly darbepoetin alfa whereas for those on once weekly regimen, darbepoetin was given once in two week which was proved to be effective and safe in maintaining target hemoglobin concentration. ${ }^{32}$

A Spanish study showed that darbepoetin alfa is more cost efficient compared with epoetin alfa for the management of anemia in patients with hemodialysis and pre-dialysis. $^{33}$

\section{IN PATIENTS WITH POST-TRANSPLANTATION}

Anemia is commonly observed after renal transplantation. Darbepoetin alfa has also been evaluated as a treatment option for anemia after transplantation. ${ }^{34}$ Pankewycz and colleagues in a prospective study have shown correction of anemia in $60 \%$ post transplant patients at 3 months. A retrospective study $(n=129)$ demonstrated effectiveness of darbepoetin alfa in reducing anemia in renal transplant patients without rise in cardiovascular events. ${ }^{35}$

In a case report, darbepoetin alfa has even been shown to be successful for the treatment of severe anemia in a pregnant woman who underwent transplant. ${ }^{36}$

In a small study $(\mathrm{n}=20)$ subcutaneous darbepoetin alfa $200 \mu \mathrm{g}$ was given every 2 weeks to the patients with post stem-cell transplantation anemia. Darbepoetin was found to be effective without any major safety concerns. ${ }^{37}$

In an observational, single center study among renal transplant patients, darbepoetin corrected anemia both in previously treated as well as EPO naïve patients. It was found to be well tolerated (Table 4$){ }^{38}$

Table 4: Summary of studies with darbepoetin alfa for the treatment of post-renal transplant anemia.

\begin{tabular}{|c|c|c|c|c|}
\hline Reference & Number of patients & Study design & $\begin{array}{l}\text { Darbepoetin } \\
\text { administration }\end{array}$ & Outcome with darbepoetin \\
\hline $\begin{array}{l}\text { Pankewycz } \\
\mathrm{O}, \text { et } \mathrm{al}^{34}\end{array}$ & $\begin{array}{l}75 \text { (total patients } \\
\text { evaluated for anemia) }\end{array}$ & $\begin{array}{l}\text { Prospective } \\
\text { study }\end{array}$ & $\begin{array}{l}\text { Standard doses } \\
\text { for three months }\end{array}$ & $\begin{array}{l}\text { Correction of anemia in } 60 \% \text { patients at } \\
\text { three months. }\end{array}$ \\
\hline $\begin{array}{l}\text { Jimenez C, } \\
\text { et al }(35)\end{array}$ & 60 & $\begin{array}{l}\text { Retrospective, } \\
\text { observational } \\
\text { study }\end{array}$ & $\begin{array}{l}\text { Darbepoetin was } \\
\text { given according } \\
\text { to clinical practice }\end{array}$ & $\begin{array}{l}\text { Given in the first week after transplant, } \\
\text { darbepoetin is effective in reducing anemia } \\
\text { during the first month without increased } \\
\text { drug related cardiovascular events }\end{array}$ \\
\hline $\begin{array}{l}\text { Ribes D, et } \\
\text { al (38) }\end{array}$ & 73 & $\begin{array}{l}\text { Observational } \\
\text { study }\end{array}$ & $\begin{array}{l}\text { Darbepoetin given } \\
\text { subcutaneously }\end{array}$ & $\begin{array}{l}\text { Darbepoetin was found to be effective } \\
\text { without any major safety concerns. }\end{array}$ \\
\hline
\end{tabular}

\section{CHILDREN AND ELDERLY}

Darbepoetin alfa has also been evaluated for its efficacy and safety in special population including children and elderly. The results in terms of outcomes in both these populations are promising. A Japanese multicentre study in children $(n=25)$ undergoing peritoneal dialysis evaluated efficacy and safety of darbepoetin for 28 weeks. Darbepoetin was administered intravenously every 2 weeks in order to keep the hemoglobin levels between 11.0 to $13.0 \mathrm{~g} / \mathrm{dL}$. If needed, dose was administered once every 4 weeks. Eighty percent patients achieved the target hemoglobin levels whereas in $60 \%$ patients the target values were maintained. Though the adverse events were reported in $44 \%$, no definite relation was observed with study drug. ${ }^{39}$ Another Japanese study evaluated efficacy and safety in CKD children $(n=31)$ on peritoneal dialysis/hemodialysis or not on dialysis. Patients on hemodialysis received IV darbepoetin alfa every week for 24 weeks whereas those on peritoneal dialysis or not on dialysis received bi-weekly dose either IV or SC. The target hemoglobin level was same as previous study. In some patients on peritoneal dialysis and not on dialysis, the dosage interval was extended to once every four weeks. In this study, all children achieved the target level of hemoglobin whereas $64.5 \%$ were in the target range at the end of the study. There was no difference in the efficacy between SC or IV route of administration. None of the adverse events reported in this study too were related to the study drug. ${ }^{40} \mathrm{Can} \mathrm{C}$ and investigators compared efficacy and safety of darbepoetin versus rHuEPO in 34 children with mean age of $11.42 \pm 4.05$ years. $^{41}$ The study population included children on hemodialysis, peritoneal dialysis as well as not on dialysis. There was no significant difference in the hemoglobin at the end of six months $(\mathrm{P}>0.05)$ between two groups. The results suggest that darbepoetin can be an effective and safe alternative to rHuEPO even in children with CKD. 
Schaefer $\mathrm{F}$ and colleagues examined the long term effects (up to 2 years) of darbepoetin in a prospective, phase IV observational study in children $(n=319) .{ }^{42}$ There were no additional safety signals. These studies demonstrate the effectiveness and safety of darbepoetin in the treatment of anemia in children with CKD. Darbepoetin has also been examined for its efficacy and safety in elderly patient population. Krause MW and colleagues conducted a post hoc subanalysis of data from two clinical trials $(n=203){ }^{43}$ In this paper the authors compared efficacy and safety of darbepoetin administered every 2 weeks in patients not on dialysis with patients younger than 65 years. The analysis suggests that elderly patients can achieve and maintain hemoglobin levels between $11.0-13.0 \mathrm{~g} / \mathrm{dL}$.

Darbepoetin alfa offers some clinical benefits over epoetin alfa:

- The half-life of darbepoetin is longer (up to three times) than rHuEPO which allows the extended dosing with darbepoetin alfa providing potential for improved compliance. ${ }^{20}$

- Subcutaneous administration of epoetin alfa is associated with the risk of pure red cell aplasia in patients with chronic renal failure. This results in limitation of its use in outpatients such as those patients not on dialysis or those receiving peritoneal dialysis. In this regards darbepoetin alfa scores over epoetin-alfa. $^{30}$

- A real-world study, has showed switching from epoetin alfa to darbepoetin alfa may result in economic advantage with less administration related errors. $^{44}$

\section{DOSE OF DARBEPOETIN}

Different starting doses are recommended for CKD patients on dialysis and for those who are not yet on dialysis. The recommended dose for patients receiving dialysis is $0.45 \mathrm{mcg} / \mathrm{kg}$ (IV/SC) weekly or $0.75 \mathrm{mcg} / \mathrm{kg}$ (IV/SC) every two weeks. Intravenous administration is recommended for patients who are on hemodialysis. The initial dose for CKD patients not on dialysis is $0.45 \mathrm{mcg} / \mathrm{kg}$ (IV/SC) every four weeks. ${ }^{19}$

\section{SAFETY OF DARBEPOETIN}

Generally darbepoetin is well tolerated. However, like other ESAs some patients may develop adverse events following administration of darbepoetin. Adverse event profile of darbepoetin is more or less similar to that of rHuEPO. The commonly reported adverse events include hypertension $(31 \%)$, dyspnea $(17 \%)$, peripheral edema (17\%), cough (12\%), postural hypotension (10\%), vascular access complications $(8 \%)$ and angina pectoris $(8 \%) .{ }^{19}$ One of the rare but clinical relevant complications associated with ESAs is development of pure red blood cell aplasia due to anti-erythropoietin antibodies against exogenously administrated ESAs. ${ }^{15}$ There is a theoretical concern regarding development of antibodies against darbepoetin leading to loss of its effectiveness; however, long term experience shows no antibodies have been reported against it, possibly because of its protective structural nature. ${ }^{18}$

\section{CONTRAINDICATIONS}

Darbepoetin alfa should be avoided in patients with history or presence of serious allergic reaction to product or excipients, uncontrolled hypertension, pure red cell aplasia after darbepoetin or other ESA. ${ }^{19}$

\section{PLACE IN THERAPY}

Erythropoietin stimulating agents have been shown to be beneficial in terms of correction of anemia, reduced need of blood transfusion improvement in quality of life, beneficial effect on left ventricular hypertrophy. However, if they are used to increase hemoglobin level more than recommended, they may cause adverse cardiovascular outcomes.

The KDIGO guideline suggests not starting ESA therapy in adult CKD patients not on dialysis if hemoglobin level is at least $10 \mathrm{~g} / \mathrm{dl}$ whereas the decision to initiate can be individualized if level is $\langle 10 \mathrm{~g} / \mathrm{dl}$. For adult patients with CKD 5D, the guideline suggest to use ESA therapy when hemoglobin level is between 9.0-10.0g and individualization of decision if level is above $10 \mathrm{~g} / \mathrm{dl}$. Generally, ESAs are not suggested for maintaining hemoglobin level above $11.5 \mathrm{~g} / \mathrm{dl}$. For children with CKD, the suggested hemoglobin level is between 11$12 \mathrm{~g} / \mathrm{dl}^{45}$ The type of ESA is selected considering its pharmacology, safety, evidence, affordability and availability. ${ }^{45}$

Darbepoetin should be used to correct anemia in CKD patient to keep the hemoglobin level between 10-12g/dl. Overuse of darbepoetin can be avoided by treating correctable cause of anemia in this patients. ${ }^{46}$

\section{ACKNOWLEDGEMENTS}

All named authors meet the ICMJE criteria for authorship for this manuscript, take responsibility for the integrity of the work as a whole, and have given final approval for the version to be published. The authors acknowledge Dr. Anant D. Patil (Plasma Medical Services) for editing this article and subsequently revising it by addressing author comments.

\section{Funding: No funding sources \\ Conflict of interest: None declared \\ Ethical approval: Not required}

\section{REFERENCES}

1. Varma PP. Prevalence of chronic kidney disease in India - Where are we heading. Indian $\mathrm{J}$ of Nephrology. 2005;25:133-5. 
2. Anupama YJ, Uma G. Prevalence of chronic kidney disease among adults in a rural community in South India: Results from the kidney disease screening (KIDS) project Indian J Nephrol. 2014;24:214-21.

3. Singh AK, Farag YMK, Mittal BV, Subramanian KK, Reddy SRK, Acharya VN, et al. Epidemiology and risk factors of chronic kidney disease in India results from the SEEK (Screening and Early Evaluation of Kidney Disease) study. BMC Nephrology. 2013;14:114.

4. Rajapurkar MM, John GT, Kirpalani AL, Abraham G, Agarwal SK, Almeida AF, et al. What do we know about chronic kidney disease in India: first report of the Indian CKD registry. BMC Nephrology 2012;13:10.

5. Hirakata H, Tsubakihara Y, Gejyo F, Nishi S, Iino Y, Watanake $\mathrm{Y}$, et al. Maintaining high hemoglobin levels improved the left ventricular mass index and quality of life scores in pre-dialysis Japanese chronic kidney disease patients. Clin Exp Nephrol. 2010;14:28-35.

6. Shaheen FAM, Souqiyyeh MZ, Al-Attar BA, Karkar A, Al Jazairi AMH, Badawi LS. Prevalence of anemia in predialysis chronic kidney disease patients. Saudi J Kidney Dis Transpl. 2011;22:456-63.

7. Horl WH, Vanrenterghem Y, Aljama P, Brunet P, Brunkhorst R, Gesualdo L, et al. OPTA: Optimal treatment of anemia in patients with chronic kidney disease (CKD). Nephrol Dial Transplant. 2007;22(3):20-6.

8. Talwar VK, Gupta HL, Shashinarayan. Clinicohaematological profile in chronic renal failure. J Assoc Physicians India. 2002;50:228-33.

9. Mudiyammanavara RN, Dhanajaya PE, Agarwal R. Cross sectional study of anaemia in chronic kidney disease. Indian Journal of Basic and Applied Medical Research. 2015;4:414-9.

10. Arun S, Venkatraya PM, Chowta NK, Bengre ML. The haematological Pattern of the Patients with Chronic Kidney Disease in a Tertiary Care Setup in South India. Journal of Clinical and Diagnostic Research. 2012;6:1003-6.

11. Schmidt RJ, Dalton CL. Treating anemia of chronic kidney disease in the primary care setting: cardiovascular outcomes and management recommendations. Osteopathic Medicine and Primary Care. 2007;1:14.

12. Kuwahara M, Hasumi S, Mandai S, Tanaka T, Shikuma S, Akita W, et al. Effects of three kinds of erythropoiesis-stimulating agents on renal anemia in Japanese non-dialysis chronic kidney disease patients. Clin Exp Nephrol. 2014;18:755-62.

13. Suzuki M, Hada Y, Akaishi M, Hiroe M, Aonuma K, Tsybakihara Y, et al. Effects of anemia correction by erythropoiesis-stimulating agents on cardiovascular function in non-dialysis patients with chronic kidney disease. Int Heart J. 2012;53:238-43.

14. Neves PL, Morgado E, Faisca M, Carrasqueira H, Baptista A, Silva AP. Nutritional and inflammatory status influence darbepoetin dose in pre-dialysis elderly patients. International Urology and Nephrology. 2006;38:811-3.

15. Lenkhorst CE, Wish JB. Anemia in renal disease: Diagnosis and management. Blood Reviews. 2010;24:39-47.

16. Carrera F, Burnier M. Use of darbepoetin alfa in the treatment of anemia of chronic kidney disease: clinical and pharmacoeconomic considerations. NDT Plus. 2009;2(1):9-17.

17. Macdougall IC, Gray SJ, Elston O, Breen C, Jenkins B, Browne J, et al. Pharmacokinetics of novel erythropoiesis stimulating protein compared with epoetin alfa in dialysis patients. J Am Soc Nephrol. 1999; 10:2392-5.

18. Macdougall IC. Darbepoetin alfa: A new therapeutic agent for renal anemia. Kidney Internationa. 2002;61(80):S55-61.

19. Aranesp (darbepoetinalfa) Prescribing information; 2011: Available from: www.accessdata.fda.gov/drugsatfda.../103951Orig1s 5173_103951Orig1s52581bl.pdf.

20. Molina M, Garcia-Hernandez MA, Navarro MJ, Perez Silva F, Cacho M,T De Gracia MC. Treatment of renal anemia with darbepoetin alfa administered once every other week in predialysis patients with chronic kidney disease and previously treated with epoetin alfa. Nefrologia. 2004;24:54-9.

21. Martinez PM, Garcia de VS, Ortega DM, Goicoechea M, Gomez CF, Luno J. Evaluation of efficacy of darbepoetin alfa administered once monthly as treatment of anemia in predialysis patients with chronic kidney disease. Nephrologia. 2005;25:663-7.

22. Koibuchi K, Miyagi M, Arai T, Aoki T, Aikawa A, Sakai K. Comparing the efficacy of continuous erythropoietin receptor activator and darbepoetin alfa treatments in Japanese patients with chronic kidney disease during the predialysis period: A propensitymatched analysis. Nephrology (Carlton). 2015;20(4):22-8.

23. Furukawa T, Okada K, Abe M, Tei R, Oikawa O, Maruyama N, et al. Randomized controlled trial of sarbepoetin $\alpha$ versus continuous erythropoietin receptor activator injected subcutaneously once every four weeks in patients with chronic kidney disease at the pre-dialysis stage. Int J Mol Sci. 2015;16:201819.

24. Hoggard J, Crouch T. McMurray S, Levine M, Prathikanti R, Scarlata D, et al. Preference for monthly darbepoetin alfa dosing in patients with chronic kidney disease not receiving dialysis. Current Medical Research and Opinion. 2006;22;10:2023-30.

25. de Lurdes ACA, Pinho A, Malho A, Morgado E, Faisca M, Carrasqueira H, et al. Risk factors for high erythropoiesis stimulating agent resistance index in pre-dialysis chronic kidney disease patients, stages 4 and 5. Int Urol Nephrol. 2011;43:835-40.

26. Bristoyiannis G, Germanos N, Grekas D, Hatzidimitriou C, latrou C, Memmos D, et al. Dosing of darbepoetin alfa for the treatment of anemia in patients with end-stage renal disease being switched 
from recombinant human erythropoietin: Results of a phase IIIb, 27-week, multicenter, open-label study in Greek patients. Current Therapeutic Research. 2005;66:195-211.

27. Agrawal V, Mukherkee S, Kosuri R, Dumler F. Anemia management with darbepoetin alfa in outpatient hemodialysis patients switched from epoetin-alfa: a community hospital experience. Am J Ther. 2010;17:469-75.

28. Alsaran K, Sabry A, Abdulghafour M, Hji M. The efficacy of monthly administration of darbepoetin alfa in Saudi hemodialysis patients. Journal of Nephrology and Renal Transplantation (JNRT). 2009;2:1-16.

29. Nguyen T, Wells D. Anemia management in adult chronic hemodialysis patients using darbepoetin alfa protocol. Dialysis and Transplantation. 2007;Oct:1-5.

30. Remon C, Quiros P, Marchena DF, Romero MH, del Castillo R, Ruiz EF. Darbepoetin alfa in the treatment of renal anemia in the patient undergoing peritoneal dialysis and previously treated with epoietin alfa. Nefrologia. 2005;225:170-7.

31. Feriani M, De Meester JMJ, McMahon LP, Rottembourg JB, Bridges I, Farouk M, et al. Extended dosing of darbepoetin alfa in peritoneal dialysis patients. BMC Nephrology. 2011;12:13.

32. Locatelli F, Canaud B, Giacardy F, Martin-Malo A, Baker N, Wilson J. Treatment of anemia in dialysis patients with unit dosing of darbepoetin alfa at a reduced dose frequency relative to recombinant human erythropoietin (rHuEpo). Nephrol Dial Transplant. 2003;18:362-9.

33. Sanz-Granda A. Probabilistic cost-minimisation analysis of darbepoetin alfa versus epoetin alfa in treating anemia secondary to chronic renal failure. Assessment in Spanish clinical practice. Farm Hosp. 2009;33:208-16.

34. Pankewycz O, Kulaylat M, Fagan L, Matthews B, Kohli R, Laftavi MR. A prospective protocol-based trial of darbepoetin alfa therapy to correct the early anemia following renal transplantation. Transplantation Proceedings. 2010;42:3537-41.

35. Jimenez C, Gonzalez E, Marques M, Galeano C, Andres A, Calvo N, et al. The impact of darbepoetin alfa in early post-transplant anemia management: retrospective exploratory study. Nefrologia. 2013;33:107-15.

36. Goshorn J, Youell TD. Darbepoetin alfa treatment for post-renal transplantation anemia during pregnancy. Am J Kidney Dis. 2005;46:e81-6.

37. Schriber J, Alvarnas J, Adoo SC, Forman S. Darbepoetin alfa is an effective therapy for anemia following allogeneic stem-cell transplantation. The Journal of Supportive Oncology. 2004;2(2):28-9.

38. Ribes D, Kamar N, Guitard J, Esposito L, Rostaing L. Darbepoetin-alfa in renal-transplant patients: an observational monocentric study. Clin Nephrol. 2008;69:102-6.

39. Hattori M, Matsunaga A, Akioka Y, Fujinaga S, Nagai T, Uemura O, et al. Darbepoetin alfa for the treatment of anemia in children undergoing peritoneal dialysis: a multicenter prospective study in Japan. Clin Exp Nephrol. 2013;17:582-8.

40. Hattori M, Uemura O, Hataya H, Ito S, Hisano M, Ohta $\mathrm{T}$, et al. Efficacy and safety of darbepoetin alfa for anemia in children with chronic kidney disease: a multicenter prospective study in Japan. Clin Exp Naphrol. 2014;18:634-41.

41. Can C, Emre S, Bilge I, Yilmaz A, Sirin A. Comparison of recombinant human erythropoietin and darbepoet in alfa in children. Pediatr Int. 2013;55:296-9.

42. Schaefer F, Hoppe B, Jungrajthmayr T, Klaus G, Pape L, Farouk M, et al. Safety and usage of darbepoetin alfa in children with chronic kidney disease: prospective registry study. Pediatr Nephrol. 2016;31:443-53.

43. Krause MW, Raja R, Agarwal A, Silver MR, Scarlata D, Sciarra A, et al. Every-other-week darbepoetin alfa in the correction and maintenance of haemoglobin levels in elderly patients with chronic kidney disease. Post Hoc subanalysis of data from two clinical trials. Drugs Aging. 2009;26:665-75.

44. Jordon J, Breckles J, Leung V, Hopkins M, Battistella M. Conversion from epoetin alfa to darbepoetin alfa: Effects on patients' hemoglobin and costs to Canadian dialysis centres. Can J Hosp Pharm. 2012;65:443-9.

45. Kidney Disease: Improving Global Outcomes (KDIGO) Anemia Work Group. KDIGO clinical practice guideline for anemia in chronic kidney disease. Kidney Inter. 2012;2:279-335.

46. Teehan G, Benz RL. An update on the controversies in anemia management in chronic kidney disease: Lessons learned and lost. Anemia; 2011. Article ID 623673.

Cite this article as: Barkate $\mathrm{H}$, Kothari $\mathrm{J}$, Patel $\mathrm{H}$, Ingale AV, Motlekar S. Darbepoetin alfa: review in the management of anemia in patients with chronic kidney disease. Int J Basic Clin Pharmacol 2017;6:474-81. 